\title{
気相成長炭素繊維の空気中における耐熱性
}

\author{
遠 藤 守 信 $^{*}$.小山恒 $*^{*}$
}

（昭和 55 年 1 月 10 日受理）

\section{Heat Resistance Properties of Vapor-grown Carbon Fibers in Air}

\author{
Morinobu Endo and Tsuneo Koyama
}

Faculty of Engineering, Shinshu University, Nagano-shi, 380, Japan

\begin{abstract}
ベンゼンと水素の混合ガスを $1000^{\circ} \mathrm{C}$ 付近で熱分解す るととによって，基板上に多量の炭素繊維が生成する。
\end{abstract} この炭素繊維は, 発生の時点からすでにwhisker 状に発 達するもので, 細孔から伸延された有機繊維の熱処理炭 化によって得られる一般の炭素繊維とは全く異なるプロ セスで形成される。著者は，乙れらの炭素繊維を一般の PAN系炭素繊維などの有機前駆体炭素繊維と区別して, 気相成長炭素繊維と称した ${ }^{1)}$ 。気相成長炭素繊維は, 構 造および物性において, 市販の有機系炭素繊維に対して 一つの理想物質とみなされ，実用上に执いても興味深い 材料である。一方, 本炭素繊維に関する種々の知見は, 一般の有機系炭素繊維の性能向上のための様々な情報を 提供するうえでも有効である ${ }^{1)}$ 。本報告は，加る気相 成長炭素繊維に関する一連の研究として, その実用上重 要となる空気中での耐熱性について検討したものである。

これまで, PAN系あるいはレーヨン系炭素繊維の耐 熱性に関しては，Mckeeらによって報告されてきだ2。 有機系炭素繊維の空気中に抢ける酸化消耗は比較的低温 度で発生して消耗率も大きく, 耐熱性は必ずしあ良好で はない。すなわち，乙れら炭素緘維の空気中での使用は， $350 \sim 400^{\circ} \mathrm{C}$ 付近が上限とみなされており，耐熱性や強 度の向上などを目的として $\mathrm{PG}, \mathrm{Zr}, \mathrm{Si}, \mathrm{BN}, \mathrm{SiC}$, Ta， TiC， TiNなどを被覆した炭素繊維が検討されて いる ${ }^{3,4,5)}$ 。

本報告論文では気相成長炭素繊維の耐熱性に関して種 種の市販炭素繊維ならびに Z r 被覆炭素繊維などの耐熱 処理繊維の挙動と比較検討し, その結果本炭素繊維は極 めて良好な耐熱性を有することが明らかとされた。こて での結果は, 一般炭素瀻維の耐熱性向上のためにも有効 な知見を与えるととができよう。

测定に用いた試料は通常の方法によって約 $1050^{\circ} \mathrm{C} の$ 温度で生成した気相成長炭素繊維 $(\mathrm{VGCF})^{1)}$ と, 同じ試 *信州大学工学部： $\bar{\top} 380$ 長野市若里
料を $2800{ }^{\circ} \mathrm{C}$ で 30 分間 $\mathrm{Ar}$ 雾团気中で熱処理して生成し た黒鉛繊維 $(\mathrm{GF}-2800)$ の二種類である。繊維直径は約 10〜30 $\mu \mathrm{m}$ である。VGCFならびにGF-2800の重量减 少曲線を熱分析装置(島津製作所製熱重量測定装置TGA -30)を用いて, 約 $5 \mathrm{~mm}$ の長さに切断した試料に関し, 室温 $1000^{\circ} \mathrm{C}$ の範囲において, 昇温速度 $5{ }^{\circ} \mathrm{C} / \mathrm{min}$, 空 気流量 $50 \mathrm{cc} / \mathrm{min}$ の条件で測定した。また空気中で, $650^{\circ} \mathrm{C}, 700^{\circ} \mathrm{C}, 800^{\circ} \mathrm{C}, 900^{\circ} \mathrm{C}$ の各温度で 1 時間加熱し た試料に関して，走査型電子顕微鏡を用いて繊維表面の 変化を観察した。なお比較のため, 処理温度がほぼ気相 成長炭素繊維の生成温度と等しい市販の PAN 系炭素繊 繊およびレーヨン系炭素繊維試料(いずれむ $1000^{\circ} \mathrm{C}$ 処 理)についても同様の実験を行った。

Fig. 1 亿, 種々の炭素繊維に関する重量変化曲線を示 す。PAN 系炭素繊維は, $450^{\circ} \mathrm{C}$ 付近から酸化消耗が発 生し, その後, 温度の上昇とともに急激な重量減少を示 す。またレーヨン系炭素纎維にあっては，PAN系炭素 繊維に比較してその酸化消耗曲線は, 約 $40^{\circ} \mathrm{C}$ ほど高温 側にシフトしたあのである。乙の結果は,レーヨンをべ 一スとした炭素繊維が, PAN系炭素㵶維に比較して耐 熱性が若干良好であるというこれまでの通念 ${ }^{3)}$ と一致し ている。なお，てれらの曲線はMckeeらによって測定 されたPAN系炭素繊維の結果 ${ }^{2}$ ともよく一致している。 一方, VGCFでは重量減少は $560^{\circ} \mathrm{C}$ 付近から開始され, $690^{\circ} \mathrm{C}$ 付近で約 $30 \%$ 重量减となることがわかる。つま り, VGCFの重量減少曲線は, PAN系などの一般の炭 素繊維に比較して $110^{\circ} \mathrm{C}$ ほど高温側に移動したあのであ り，その耐熱性がより優れているととが明らかである。 またMckeeは，2500 3000 ${ }^{\circ} \mathrm{C}$ で熱処理したPAN系黒 鉛繊維の重量减少は, 約 $590 \sim 640^{\circ} \mathrm{C}$ で開始するととを 示しているが2)，VGCF の酎熱性は，その生成温度が $1050^{\circ} \mathrm{C}$ と低いにもかかわらず，乙れらの黒鉛化処理を 施した有機系炭素繊維とほぼ等しい耐熱性を有すること 


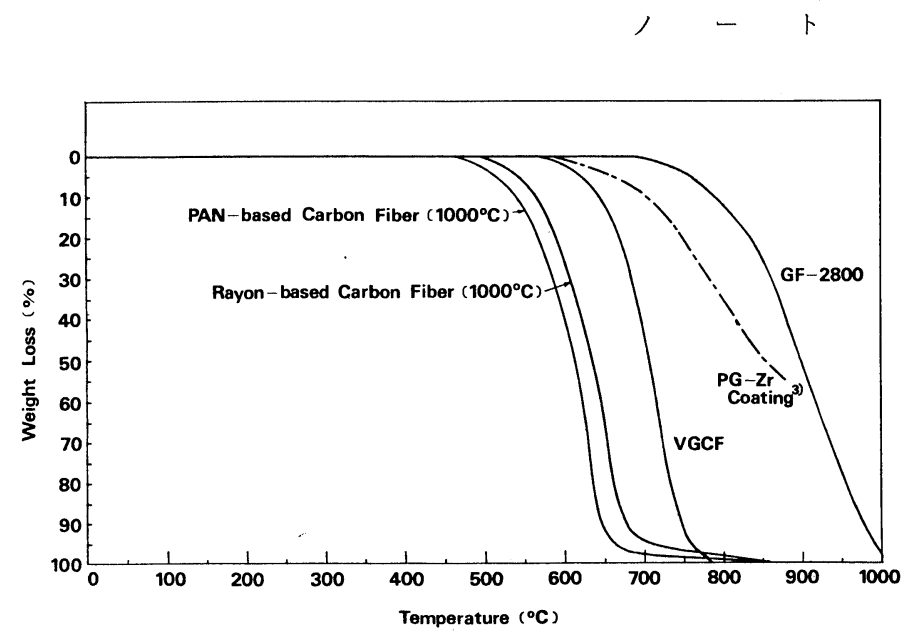

Fig. 1. Thermograms for the oxidation in air of vapor-grown carbon fibers, obtained at $1050{ }^{\circ} \mathrm{C}$ by pyrolysing hydrogen-diluted benzene (VGCF), and of graphite fibers prepared by heat treatment of VGCF at $2800{ }^{\circ} \mathrm{C}$ (GF-2800). PAN- and rayon-based carbon fibers are comparatively examined. Heating rate $5{ }^{\circ} \mathrm{C} / \mathrm{min}$., air flow rate $50 \mathrm{cc} / \mathrm{min}$.

がわかる。一方， GF-2800 の酸化消耗は， $700^{\circ} \mathrm{C}$ 付近 加発生し，温度上昇に対する重量減少率む他の炭素緎 維と比較してより緩慢である。GF-2800は, 繊維に表 面処理を施してない単味の繊維状炭素材料中では最も 優れた耐熱性瀻維といえよう。なお，実験条件などの違 いもあり厳密な比較は難しいが， $\mathrm{PG}-\mathrm{Zr}$ 被覆を施した 耐熱性炭素繊維 ${ }^{3)}$ に比べても(Fig. 1)，GF-2800はよ り優れた耐熱性能を持つ可能性が高い。

VGCFならびに GF-2800の良好な耐熱性は，その年 輪状の断面構造や繊維軸に沿った炭素層面の高度な配向 性, マイクロポアーの無い高い維密性などが反映された あのと考えられる ${ }^{6,7)}$ 。さらに, 酸化消耗を発生しやす いとみられるアモルファスカーボン成分が ${ }^{2)}$, 有機系炭 素䋐維に比較してGF-2800ではむちろん，VGCFにお いてもほとんど含まれていないととによるとも考えられ る。通常の低弾性率炭素繊維に抢いては $1 \%$ の重量損失 を生ずる時間は $493^{\circ} \mathrm{C}$ で 1 時間, $310^{\circ} \mathrm{C}$ で 1000 時間程度 であり, 空気中での安全使用温度は $300 \sim 350^{\circ} \mathrm{C}$, また 高弾性品では $400^{\circ} \mathrm{C}$ 前後とみられている ${ }^{3)}$ 。上述の重量 減少曲線から推定して, 空気中での安全使用温度は, VGCF で〜 $400^{\circ} \mathrm{C}, \mathrm{GF}-2800$ では〜 $550^{\circ} \mathrm{C}$ 程度となろ う。

Fig. 2 亿, 空気中で加熱処理したVGCF の表面 SEM 写真を示す。VGCFでは $650^{\circ} \mathrm{C} て ゙ 1$ 時間熱処理した場合 には, 約 $0.8 \mu \mathrm{m}$ の直径を有した円形に近いピットの発生 が観察される(Fig. 2, A)。熱処理が $700^{\circ} \mathrm{C}, 1$ 時間の場 合(Fig. 2, B)は，酸化が著しく進展し，比較的大きな
ピットの直径は約 1〜2 $\mu \mathrm{m}$ になる。かか るピットは円筒状であり,ピットの平ら な底面に次の円筒状ピットが形成されて いる(Fig. 2，C)。乙れは繊維表面に発生 した微小なピットが径方向に成長し，そ の後ピットの底面に新たなピットが発生 したもので, 年輪状の断面構造と関係し たあのと考えられる。

Fig. 3は, GF-2800の酸化後の SEM 写真である。 $800^{\circ} \mathrm{C}$ で 1 時間熱処理して あ，ピットの発生はほとんど認められな い。極めてまれに図A，B佂すような 紡鍾形や多角形状のピットが観測される。 さらに $900^{\circ} \mathrm{C}$ で 30 分〜 1 時間処理する場 合であ，Fig. 3, C, D佰すように，低 温度で形成されたピットがより大きく成 長するのみで, 発生ピット数は特に増加 していない。ピットは深さ方向の成長よ りも, むしろ半径方向の成長が著しいが これは年輪状の層面構造が反映されたあのと考えられ

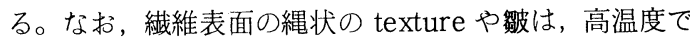
熱処理されたVGCF に発生するあので，酸化処理とは 関係していない。以上より，GF-2800 はVGCFに比較 して，耐熱性が著しく改善されていることが明らかであ る。

このようなVGCF およびGF-2800の酸化消耗の挙動 は，有機系炭素繊維の場合と著しく異なる。すなわち， PAN 系炭素繊維では，酸化の進展とともにピットが発 生し ${ }^{2)}$, 繊維径む一様に減少してその表面はより平滑に なる(Fig. 4)。かかる差異は, 繊維構造が反映されたも のであろう。つまり，気相成長炭素繊維の表面は炭素六 角網平面で覆われているのに対し，有機系炭素繊維では 炭素網平面のエッジが繊維表面に多く露出した構造のた めとみられる。VGCF の高い耐熱性は, 主にその炭素 層面の緻密性の高い年輪状配列によってもたらされると 考えられる。黒鉛化処理したGF-2800では，かかる構 造がより完全なものとなっており，酸化ピットの形状も 黒鉛結晶の場合と類似している ${ }^{8)}$ 。

推定される酸化消耗のモデル図をFig. 5 亿まとめて示 $す^{9)}$ 。以上から, 有機系炭素繊維に対しても本繊維と同 様な年輪状の構造(例えばメソフェースピッチ系炭素縉 維における onion skin 構造)を付与するととによって， その耐熱性を向上させるととが可能であろう。

本研究に対して, 日頃種々ご指導賜わる豊橋技科大・ 稲垣道夫教授，また炭素繊維に関して広くご討論賜わる 群馬大学・大谷杉郎教授ならびに試料の熱処理にご協力 

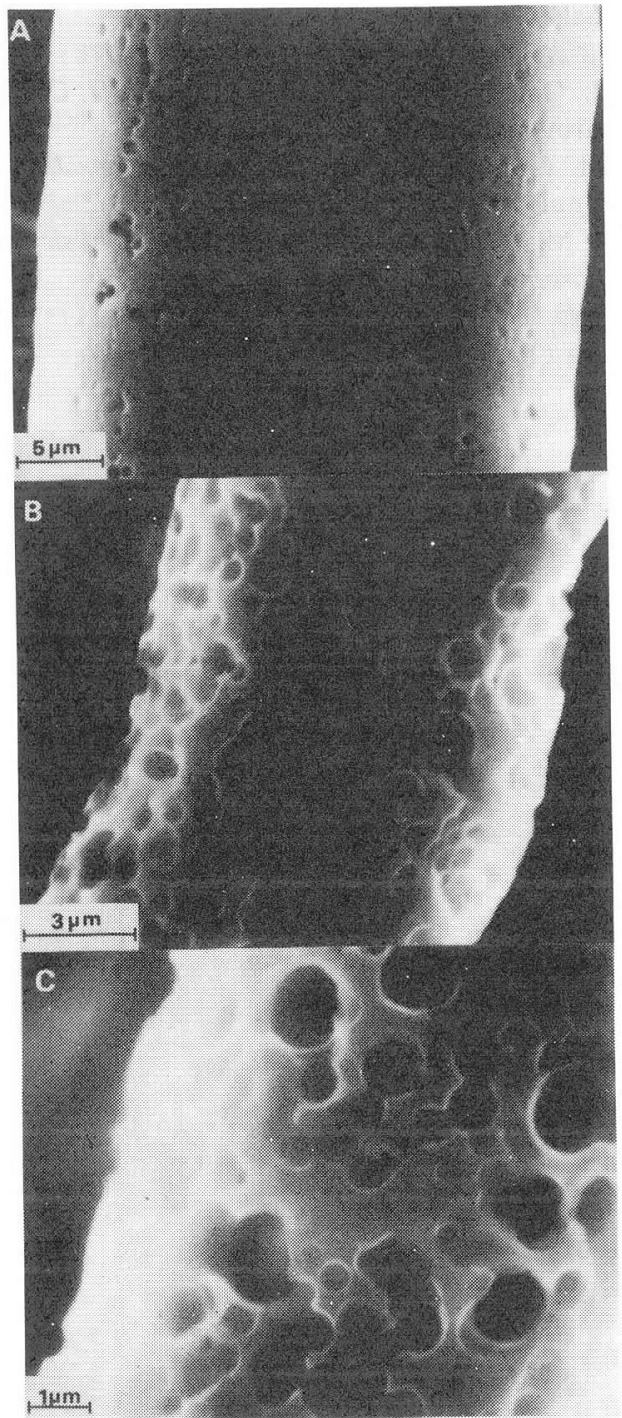

Fig. 2. SEM pictures of VGCF after heat treatment in the air at $650^{\circ} \mathrm{C}$ for $1 \mathrm{hr}(\mathrm{A})$, and at $700^{\circ} \mathrm{C}$ for $1 \mathrm{hr}(\mathrm{B}, \mathrm{C})$.

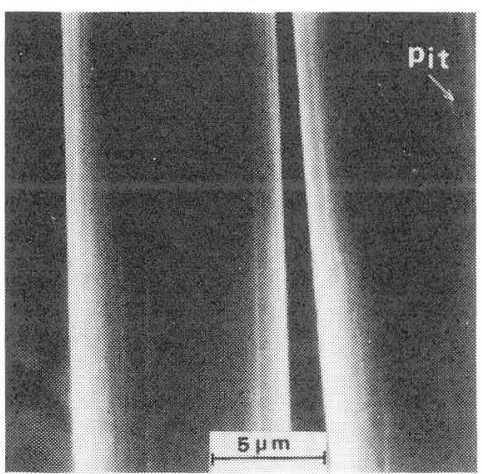

Fig. 4. PAN-based carbon fiber surface after oxidation in air for $1 \mathrm{hr}$ at $700^{\circ} \mathrm{C}$.

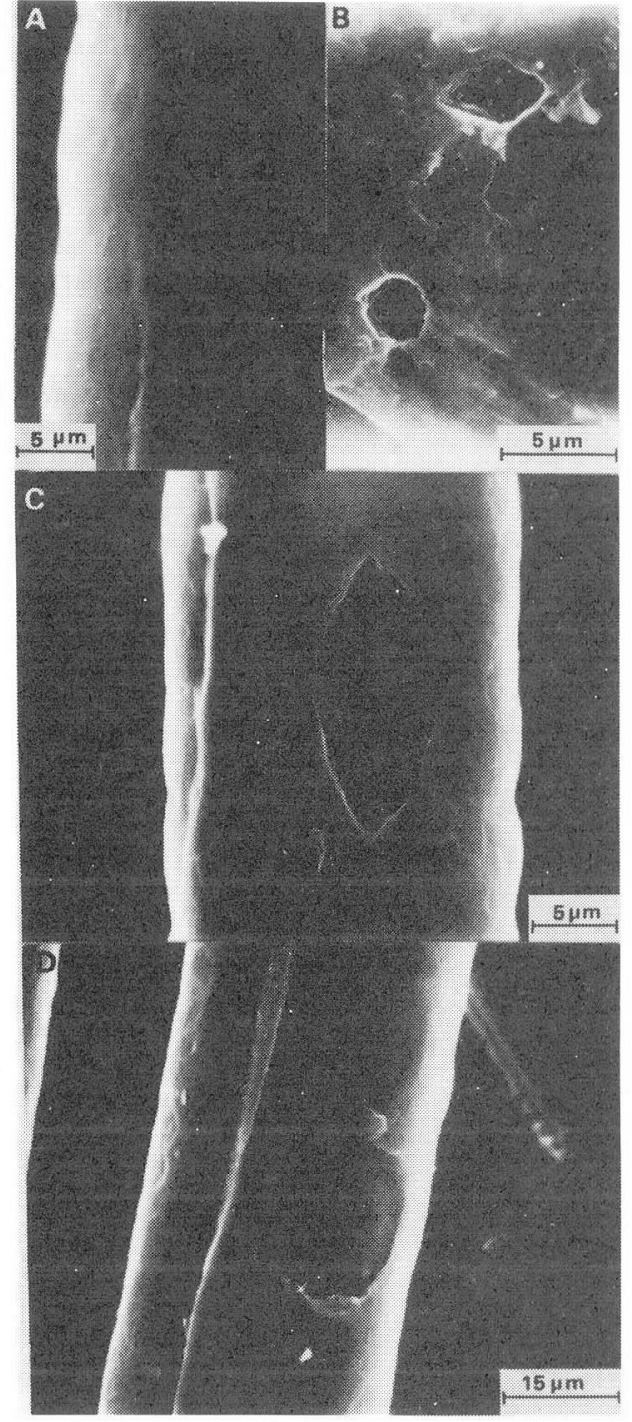

Fig. 3. SEM pictures of GF-2800 after heat treatment at $800^{\circ} \mathrm{C}$ for $1 \mathrm{hr}(\mathrm{A}, \mathrm{B})$, and at $900^{\circ} \mathrm{C}$ for $30 \mathrm{~min} . \sim 1 \mathrm{hr}(\mathrm{C}, \mathrm{D})$.

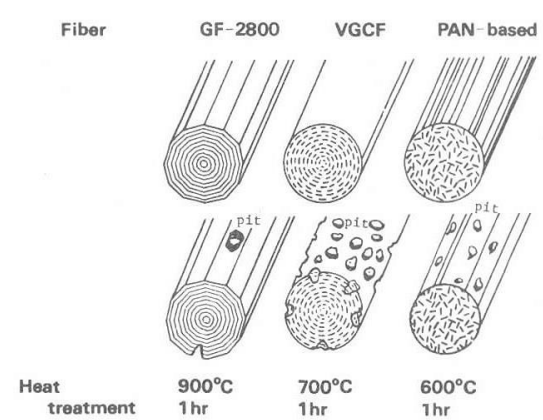

Fig. 5. Schematic representation of the structure and oxidation behavior of VGCF, GF-2800 and PAN-based carbon fibers. 
いただいた大谷朝男博士に厚く御礼申し上げる。なお， 本研究は一部文部省科学研究費 (昭和 54 年度) の援助に よった。

\section{文献}

1) 遠藤, 小山：固体物理 12, 1（1977）

2) D.W. Mckee and V.J. Mimeault: Chemistry and Physics of Carbon 8, 151 (1973)

3) 大谷: 炭素繊維, p. 81 (1972)近代編集社

4) L. Aggour, E. Fitzer, E. Ignotowitz and M.
Sahebkar: Carbon 12, 358 (1974)

5) 遠藤, 小山, 小松: 材料科学 13,39 (1976)

6) A. Oberlin, M. Endo and T. Koyama: J. Crystal Growth 32, 335 (1976)

7) M. Endo, T. Koyama and A. Oberlin: Jpn. J. Appl. Phys. 16, 1519 (1977)

8) J. M. Thomas: Chemistry and Physics of Carbon 1, 122 (1965)

9) 遫藤, 小山：学術振興会 117 委員会資料 117-157B3 (1979) 